\title{
Divisia Index Monetary Aggregates: Do They Matter for Monetary Policy in Malaysia?
}

\author{
JAUHARI DAHALAN \\ Faculty of Economics \\ Universiti Utara Malaysia
}

\begin{abstract}
Divisia for narrowly and broadly defined monetary aggregate of a developing country, Malaysia, are constructed. Unlike the Divisia for narrowly defined monetary aggregate M1, the Divisia for broader defined monetary aggregate M2 does show significant differences in both level and growth rates that signified the degree of the important and usefulness of Divisia index in formulating the monetary policy. We ascertained that there exist long-run relationships between all measures of monetary aggregates in this study with inflations. By constructing dynamic error-correction models for all the alternative measures of monetary aggregates, we performed out-of-sample forecasting for three different periods. Analysis of the forecasting statistics indicates that the Divisia monetary aggregates performed better than their simple-sum counterparts in forecasting ability. We conclude that Divisia monetary aggregate namely Divisia M2, has the best forecast ability among all. As such, Divisia M2 can serve as an excellent candidate as a target or indicator in formulating the monetary policy for Malaysia.
\end{abstract}

Key words: Divisia, simple-sum, monetary aggregates, unit root, ECM, root mean square error, root mean absolute error, root mean absolute percentage error.

\footnotetext{
ABSTRAK

Kajian ini menghasilkan Divisia indeks bagi definasi agregat wang secara kecil dan wang secara besar untuk sebuah negara yang membangun iaitu, negara Malaysia. Divisia agregat wang M1 yang didefinasikan sebagai wang secara kecil berbeza dengan Divisia yang didefinisikan sebagai wang secara besar iaitu aggregate M2. Ianya menunjukkan perbezaan yang ketara dari segi tahap dan juga kadar pertumbuhannya. Ini menunjukkan penyerelahan nilai-nilai penting dan bergunanya Divisia indeks dalam merangka polisi kewangan negara. Dengan menggunakan kaedah ko-integerasi, kajian juga menunjukkan wujud hubungan jangka masa panjang bagi semua ukuran agregat wang dengan inflasi. Dengan pembentukan model pembetulan ralat bagi semua alternatif ukuran agregat wang, peramalan luar sampel bagi tiga tempoh masa yang berbeza dilakukan. Analisis statistik peramalan menunjukkan agregat wang Divisia menghasilkan peramalan yang lebih baik berbanding agregat wang penjumlahan mudah. Kami merumuskan bahawa agregat wang Divisia terutamanya Divisia M2, mempunyai keupayaan peramalan yang lebih baik berbanding dengan lain-lain agregat wang. Dengan itu, Divisia M2 boleh dijadikan calon yang terbaik sebagai sasaran atau petunjuk dalam merangka polisi kewangan yang berkesan bagi negara Malaysia.
} 


\section{INTRODUCTION}

Malaysia has implemented major financial liberalization since the late 1970s, the first major step being the deregulation of interest rates. Financial deepening and innovation continued steadily and have contributed to the development of a modern and sophisticated financial system in Malaysia (Bank Negara Malaysia, 1999). The negotiable certificates of deposit (NCDs), bankers' acceptances (BAs), and repurchase agreements (REPOS) were introduced by the central bank in 1979 to increase the variety of money market papers. While NCDs were designed as instruments to mobilize savings, BAs were introduced as an easy financing tool to promote trade. The removal of credit ceilings and liberation of interest rates in the late 1970s paved the way for greater financial sector reforms. Increased globalization of the financial sector has also precipitated further changes in the framework of the monetary policy in Malaysia. As a result, simple-sum monetary aggregates may not be the appropriate indicators of the conduct of monetary policy.

In Malaysia, Bank Negara Malaysia (BNM) - the central bank, is responsible for the formulation and implementation of monetary policy to attain price stability. As such, the BNM constantly review the monetary policy framework to ensure that it remains relevant amid the dynamic changes in the financial and economic environment. Early 1990s marked a major milestone in the conduct of monetary policy, which saw significant changes in terms of strategies, approaches and instruments. The removal of credit ceilings and liberalization of interest rates in the late 1970s paved the way for greater financial reforms that also rely more on markets for determining interest rates. As a result, the central bank shifted its monetary policy strategy from monetary targeting towards interest rates targeting towards the mid-1990s (Bank Negara Malaysia, 1999).

As Friedman and Schwartz (1970) observed, it is unlikely to construct an appropriate monetary aggregate by simply summing monetary components. Yet this is the practice most commonly adopted by monetary authorities. This procedure treats all included assets alike in their 'moneyness', and excluded assets are assumed to possess no moneyness or to provide no monetary services. It seems, however, highly unlikely that all the included assets have identical monetary attributes. According to Barnett (1980), the traditional simple-sum monetary aggregate approach of measuring money is an incorrect measurement of the flow of monetary services. Barnett (1980) argues that simple-sum monetary aggregates are calculated on the assumption that their components receive equal weights of one and are therefore considered to be perfect substitutes, which means that the elasticity of substitution between any pair of components is infinite. This linear aggregation according to Barnett (1980) is unacceptable. Barnett (1980) points out that when asset components are not perfect substitutes, nonlinear aggregation is required with different weights attached to each component asset. Thus, the meaningful economic measure would be a weighted-sum aggregate with weights reflecting relevant value shares. The weights vary from zero, which reflects no monetary service to one denoting pure money. Given this view, Barnett (1980) advocates the use of a Divisia monetary index as an alternative to the traditional simple-sum monetary aggregates.

Past work on the Divisia monetary index has supported the construction of a weighted sum that is based on the degree of liquidity of each component of monetary asset. Divisia indices have been constructed by Cockerline and Murray (1981), and Serletis and King (1993) for Canada; Ishida (1984), and Ishida and Nakamura (2000) for Japan; Barnett, Offenbacher, and Spindt (1984), and Chou (1991) for the United States; Belongia and Chrystal (1991), and Spencer (1994) for the United Kingdom; Yue and Fluri (1991), and Fluri and Spoerndli (2000) for Switzerland; Lim and Martin (2000) for Australia; and Janssen and Kool (2000) for Netherlands and German. The results of these studies suggest that divisia monetary aggregates are preferred over traditional simple-sum monetary aggregates in conducting monetary policy. In addition, Habibullah (1999) in his study of the selected Asian developing economies also concludes that the Divisia monetary aggregates are potentially useful as indicators for monetary policy purposes. Despite the theoretical implication of the Divisia approach as an appropri- 
ate measure of monetary aggregates and its implication towards formulating monetary policy, the existing studies have been limited to developed countries. An empirical testing of the performance of Divisia monetary aggregates in developing countries, therefore, can be useful in ascertaining the robustness of the conclusion derived for developed countries.

There are three purposes of this paper. Since many of the developing countries have undergone significant changes toward financial deregulation and innovation since the late 1970s, it is the objective of this paper firstly to construct the Divisia monetary aggregates M1 and M2 for Malaysia, and to discuss its behavior with respect to traditional simple-sum monetary aggregates. The second objective of this paper is to examine the stationary long-run relationship and short-run dynamic between the monetary aggregates and the inflation. The third objective is to determine the forecasting ability of each monetary aggregate. For this purpose, we performed out-of sample forecast of inflations for three periods using the estimated error-correction models of the alternative monetary aggregate measures.

The remainder of the paper is structured as follows. Section II presents the theoretical framework that underpins the empirical analysis. Comparison between the simple-sum and Divisia index of monetary aggregate measures are presented in Section III. Section IV reports and discusses the results of the study, and their implications for the efficacy of monetary policy are presented in the concluding section, Section V.

\section{METHODOLOGY AND DATA}

\section{Constructing Divisia Indexes}

First, it is important to identify the admissible monetary assets for the construction of consistent and meaningful monetary aggregates. To construct the Divisia monetary aggregates for Malaysia, the component of monetary assets are based on the definitions of M1 and M2. The components of monetary assets are currency in circulation, demand deposits, savings deposits, fixed deposits, negotiable certificates of deposit, and repurchase agreements.
We will follow the definition of the monetary aggregates in Malaysia as defined by the central bank of Malaysia - Bank Negara Malaysia (BNM). M1 is composed of the currency in circulation and demand deposits and M2 includes M1 plus savings deposits (SVD), fixed deposits (FXD), negotiable certificates of deposit (NCD), and repurchase agreements (REPOS). The savings deposits, fixed deposits, negotiable certificates of deposits and repurchase agreements are also known as quasi-money.

Following Barnett, W. A. (1980); Barnett, W. A., Offenbacher, E., and Spindt, P. $(1981 ; 1984)$, the Tornquist-Theil discrete time approximation to the Divisia quantity index is used here in the computation of the Divisia monetary aggregates (DM) which is given as follows:

$$
\begin{aligned}
\log D M_{t}-\log D M_{t-1}=\sum^{N}{ }_{i=1} S_{i t}^{*}\left(\log M_{i t}\right. & \left.-\log M_{i t-1}\right)
\end{aligned}
$$

where $S_{i t}^{*}$ is the average of $S_{i t}$ and $S_{i t-1}, M_{i t}$ represents the balance of asset $i$ at time $t$, and $S_{i t}$ is defined as expenditure shares of monetary asset $i$ at time $t$. Given the user cost, that is, prices and quantities of each monetary asset, $S_{i t}$ can be computed as follows:

$$
S_{i t}=\pi_{i t} M_{i t} / \sum^{N}{ }_{j=1} p_{j t} M_{j t}
$$

where $\pi_{i t}$ is the user cost of each monetary asset. Following Barnett (1978) price of the transaction service of each monetary asset, or the user cost of each monetary asset, is defined as:

$$
\pi_{i t}=P_{t}\left(R_{t}-r_{i t}\right) /\left(1+R_{t}\right)
$$

where $\pi_{i t}$ is the user cost of asset $i$ at time $t, R_{t}$ is the benchmark rate at time $t$, and $r_{i t}$ is the own rate of the asset $i$ at time $t$, and $P_{t}$ is the consumer price index.

In order to calculate user costs or rental prices of the monetary assets, it is necessary to select an asset to serve as the benchmark asset that does not provide any monetary service and whose rate of return should not be less than the rates of return of the monetary assets. In theory, the benchmark rate of return is defined as the maximum expected holding period yield of a pure 
store-of-value asset. This benchmark asset is specifically assumed to provide no liquidity or other monetary service and held solely to transfer wealth intertemporally. The benchmark rate as adopted by Barnett, and Spindt (1982) is the highest interest rate between bond rates and the maximum among all own rates of component assets at each point in time. The role of the benchmark asset as explained by Barnett, Fisher, and Serletis (1992) is to establish a nonmonetary alternative. It is acceptable for this to be a different asset in each period, since maximization is repeated in each period. In the case of Malaysia, where data on corporate bonds is not readily available the other viable alternative assets that is the treasury bills and the government securities are included to compute benchmark rate. Thus, the maximum among own rates at each point in time is chosen as the benchmark rate, that is,

$$
\begin{aligned}
R_{t}= & \max \left\{R D D_{t}, R S V D_{t}, R F X D_{t},\right. \\
& \left.R N C D_{t} \operatorname{RREPOS}_{t} Y G S_{i t}\right\}
\end{aligned}
$$

where RDD is the own rate of return on demand deposits, RSVD is the own rate of return on savings deposits, RFXD is the own rate of return on fixed deposits, RNCD is the own rate of return on negotiable certificates of deposit, and RREPOS is the own rate of return on repurchase agreements, and YGS represents the return on the treasury bills and yield on government securities. Here, $i$ represents 3 and 12 months treasury bills, and 5, 10 and 20-year maturities government securities. Following Anderson, Jones, and Nesmith (1997), the benchmark rate during each time period $t$ is:

$$
R_{t}=\max \left\{r_{i t}(i=1,2, \ldots, n), r_{B A A, t}\right\}+c
$$

where $r_{i t}$ is the own rate of return on monetary asset $i$ at time $t, r_{B A A, t}$ is the own rate of return on Moody's seasoned BAA bonds at time $t$, and $c$ is a small constant. The inclusion of the constant is to guarantee that the benchmark rate is always greater than the rate of any monetary asset. As suggested by Anderson et al. (1997), this constant is set at one basis point or less. Following this procedure the benchmark rate for Malaysia is derived as follows:

$$
\begin{aligned}
R_{t}= & \max \left\{R D D_{t} R S V D_{t} R F X D_{i}\right. \\
& \left.R N C D_{t} R_{t} R E P O S_{i} Y G S_{i t}\right\}+0.0001
\end{aligned}
$$

Next, following Klein (1974) the fully competitive implicit rate of return on demand deposits, is expressed as follows:

$$
r_{D}=\mathrm{r}_{1}(1-[R / D])
$$

where is $r_{D}$ the implicit interest rate on demand deposits, $r_{l}$ is the rate of return on investment or alternative asset, and R/D is the ratio of reserves to deposits. However, according to Starz (1979), the fully competitive rate by Klein (1974) is rather high. Starz (1979) suggested that the implicit rate of return for demand deposits is between 0.34 and 0.58 times the fully competitive rate suggested by Klein (1974). Thus, following Starz (1979), the implicit rate of return on demand deposit for Malaysia is calculated as:

$$
r_{D}=\mathrm{r}_{1}(1-[R / D])(\alpha)
$$

where $r_{l}$ is the commercial bank's base lending rate, $R / D$ is the maximum reserve requirement on demand deposits. _ is set equal to 0.58 which is its maximum value. Indeed, this value of _allows an implicit rate which is comparable to the own rate of return of savings deposits (RSVD) offered by the commercial banks as shown in Figure 1. (Habibullah, 1999), does not include Starz (1979), thus computational of Divisia index in this study is somewhat different from Habibullah (1999).

\section{Unit Root Test}

In this study, the relationship between the Malaysian alternative monetary aggregates and inflations are compared. In order to facilitate a comparison of the performance of the alternative monetary aggregates, it is important firstly to establish the long-run relationships between inflation and monetary aggregates by means of cointegration test. Testing for cointegration involves testing to establish that variables in question are integrated in the same order. This involves the preliminary tests of the stationarity of the individual series of interest. The series to be tested are the Divisia index M1 and M2, simple-sum M1 and $\mathrm{M} 2$, and inflation. The series for inflation is 
Figure 1:

Implicit rate of return of demand deposits (RDD)

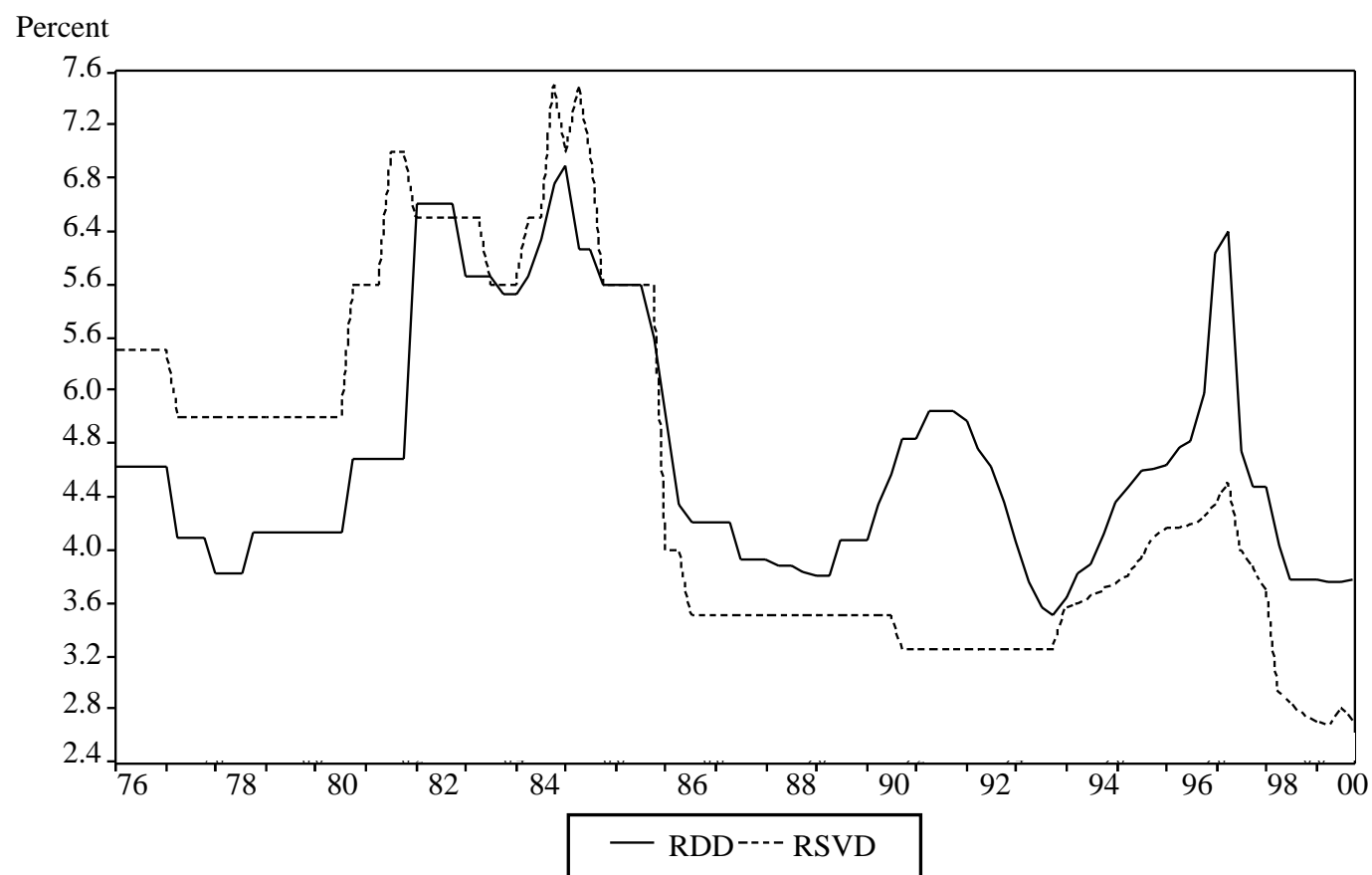

computed from the price index. All series are logged and all series are in real term except for inflation. To establish stationarity of the series is to test for the present of the unit root, and this is done by way of the augmented Dickey-Fuller (ADF) tests.

The ADF approach is the $t$ statistics test on $\alpha$ which is based on a process with a non-zeromean and a process with non-zero mean and linear time trend. The regression models for these processes are shown as follows:

$$
\begin{aligned}
& \Delta X_{t}=\mu+\alpha^{*} X_{t-1}+\sum_{i=2}^{p} \delta_{i} \Delta X_{t-i+1}+\mu_{t} \\
& \Delta X_{t}=\mu+\beta_{t}+\alpha^{*} X_{t-1}+\sum_{i=2}^{p} \delta_{i} \Delta X_{t-i+1}+\mu_{t}
\end{aligned}
$$

where $\mu$ is the non-zero mean, $t$ is the linear time trend term. $X_{t}$ represents the series, Divisia M1, Divisia M2, simple-sum M1, simple-sum M2 and inflations. The stationary process for (9) is tested under the null hypothesis of having a unit root in the series that is, $\mathrm{H}_{0}: \alpha^{*}=0$, using the computed $t$ statistics which given a $t_{\alpha^{*}}$. Similarly, for (10) the $\mathrm{t}$ statistics is computed as for testing the null hypothesis of unit root that is $\mathrm{H}_{0}: \alpha=0$.

\section{Cointegration Test and Error-Correction Model} (ECM)

In order to establish a long-run relationship between inflation and the alternative money measures, the series must be cointegrated. Two or more non-stationary time series are said to be cointegrated if the linear combination of these series are cointegrated. In this study the cointegration between inflation and alternative money measures are tested by means of residualsbased on the Engle-Granger (1987) cointegration test procedure. In this procedure, the DickeyFuller (DF) and augmented Dickey-Fuller (ADF) tests are applied to the ordinary least square residuals of the cointegration equations.

However, this cointegration relationship gives only the long-run equilibrium among the variables. For some purposes such as forecasting, one is interested in the short-run evolution of the variable, which will require the specification of 
some dynamic model. Engle and Granger (1987) proposed a dynamic model which is called the error-correction model which can be described as follows:

$$
\begin{aligned}
\Delta Y_{t}= & \alpha_{1}+\alpha_{y}\left(Y_{t-1}-\beta_{l} X_{t-1}\right)+\sum_{i=1}^{p} \alpha_{11}^{i} \Delta Y_{t-1}+ \\
& \sum_{i=1}^{q} \alpha_{12}^{i} \Delta X_{t-1}+\varepsilon_{Y t}
\end{aligned}
$$

In this model, both short-run and longrun effects are incorporated and includes only stationary variables and hence, reduces the risk of spurious regression outcome. As for the estimation of this model, the coefficient of the variable in parenthesis indicates how the changes in variable $\mathrm{Y}$ respond to any disequilibrium in the longrun relationship.

Thus, the concept of cointegration is very important in the modeling and estimation of error-correction models (ECM). By using error-correction models, it is possible to evaluate the longrun influence of the various measures of the monetary aggregates on inflations or prices and to compare their performance as intermediate monetary targets in formulating monetary policy. In this study we developed error-correction models for all alternative measures of monetary aggregates namely Divisia M1, Divisia M2, simple-sum M1 and simple-sum M2. The error-correction model for each monetary aggregate is given as follows:

$$
\begin{aligned}
\Delta \log I N F L_{t}= & \text { const }+E C T_{t-1}+\sum_{i=1}^{p} \Delta \log I N F L_{t-\mathrm{i}} \\
& +\sum_{i=1}^{q} \Delta \log M_{t-\mathrm{i}}+\varepsilon_{\tau}
\end{aligned}
$$

The error-correction terms (ECT) used in the regressions are the residuals of ordinary least square of the respective cointegration relationship of the various measures of monetary aggregates and inflations. Using this error-correction models we estimate the effect of the growth of each measure of monetary aggregate on the inflation rate. We next forecast inflation over different periods using the error-correction models.

The empirical work outlined in subsequent sections employs quarterly data from 1976Q1 to 2000Q4. The year 1976 is chosen as the beginning of the sample as financial develop- ment and deregulation took off in the late 1970's and early 1980's. Data on interest rates such as fixed deposit rates (various maturities), saving deposit rates, negotiable certificate of deposits rate, treasury bill rates (various maturities), government securities yields (various maturities), base lending rate, and reserve requirement (SSR) are obtained from Bank Negara Malaysia (the central bank of Malaysia) and SEACEN Financial Statistics. In addition, other data such as M1, M2, demand deposits, saving deposits, NCDs, and REPOS are obtained from the same sources. Other data such as consumer price index is taken from International Monetary Statistics (IFS) CD-ROM database of International Monetary Fund.

\section{A Comparison of the Behaviour of Divisia and Simple Sum Monetary Aggregates}

It is imperative to make a comparison to see how the monetary policy or other issues might be affected by the method of aggregation. Since the Divisia monetary aggregates is an alternative to conventional simple-sum aggregates, a comparison of its historical behavior may be instructive. The simple-sum and Divisia index of monetary aggregate measures are normalized, that is, equal 100 in 1976Q1.

Figure 2 shows quarterly data on the level of nominal simple-sum M1 (SM1) as traditionally measured, superimposed on the level of the Divisia index for M1 (DM1). Both the simplesum and Divisia M1 demonstrate an increasing trend but drop significantly in 1997 and 1999, the periods of financial crisis. A comparison of simple-sum and Divisia M1 reveals that the liquidity increased more with the simple-sum, as compared to Divisia. Nevertheless, both look quite similar. However, a significant divergence of the two began in 1988 but continued to move in similar directions. Comparing the shares of component of simple-sum and Divisia M1 indicates that the respective shares of the monetary components moved uniformly regardless of the methods of aggregation adopted. This reflects that in the case of M1, the contribution of these monetary components to the different types of monetary aggregation, simple-sum and Divisia index, are basically the same. 
Figure 2:

Divisia index (DM1) and simple-sum M1 (SM1)

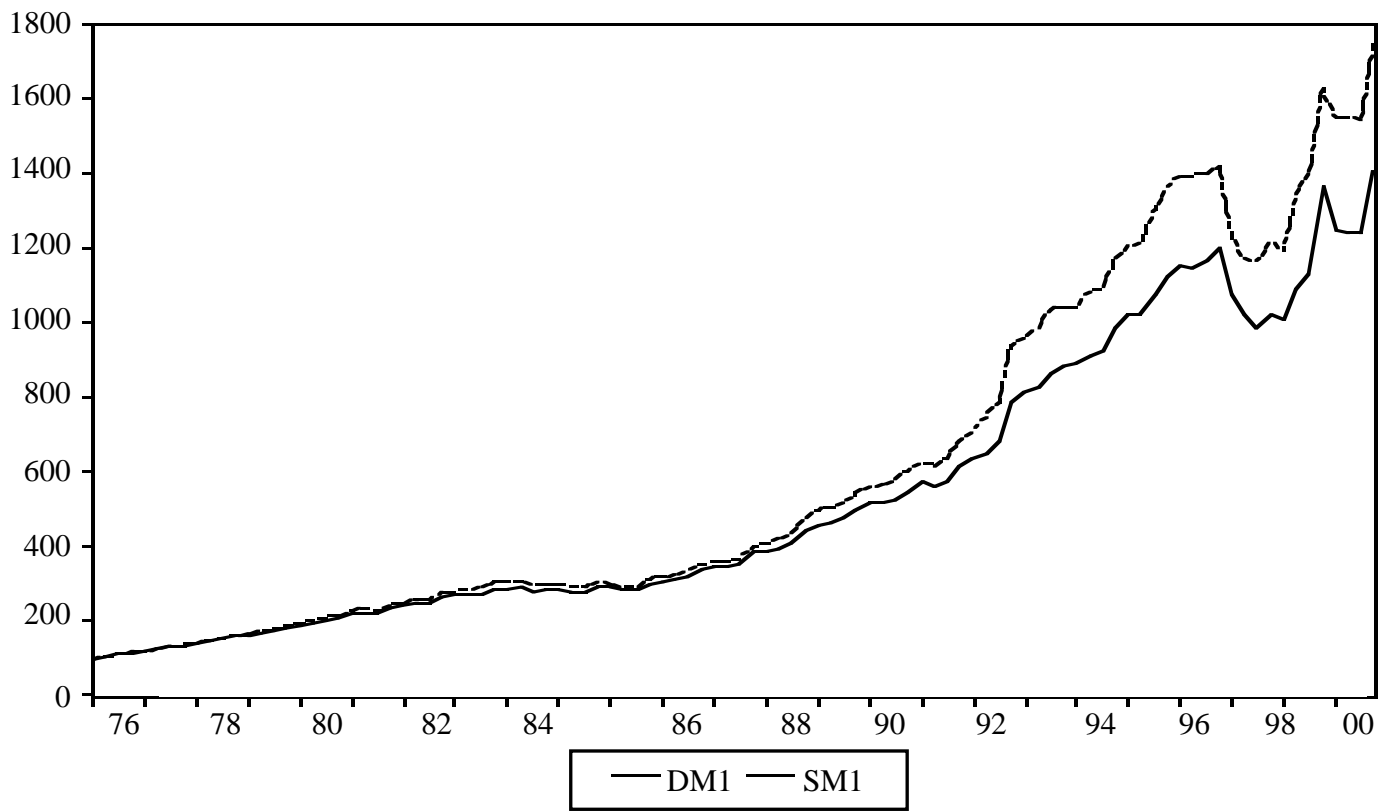

The currency component of M1 remained relatively stable until 1997 . Generally, the fluctuations in M1 have come from variations in demand deposits. The cash in the hands of the nonbank private sector declined due to the improvements in the payments mechanism which allowed the public to economize on cash balances (Bank Negara Malaysia, 1994). On the other hand, the strong growth in demand deposits rose mainly from higher transactional demand by business enterprises and individuals, which reflects strong economic activities during the period up to 1997 and the Asian financial crisis (Bank Negara Malaysia, 1994; 1999).

Figure 3 shows the traditional simplesum measure M2 (SM2) with Divisia M2 (DM2). SM2 grew more rapidly than the corresponding Divisia index. Both show an increasing trend except during 1999 where both dipped as a result of the financial crisis. Both seem to have identical trends, although the two began to diverge in 1984. This divergence is suspected due to the introduction of the financial products and instruments in the financial market as well as deregulation of interest rates which commenced in late 1978. In
1979, negotiable certificates of deposit (NCDS) which were designed as instruments to mobilize savings, and repurchase agreements (REPOS) were introduced by the Central Bank of Malaysia to extend the variety of money market papers.

The simple-sum procedure of monetary aggregation weights these assets equally with currency in their contribution to M2 whereas Divisia weights them less. More generally, the Divisia aggregation gives lower weights to monetary assets that yield higher rates of return. Thus, a higher own-rate tends to reduce the quantity of the asset that is held and its expenditure share weight falls in a Divisia index due to the lower user costs. This explains the divergence of Divisia from simplesum M2. The introduction of the new financial innovations reflects that the Malaysian financial structure has indeed undergone a remarkable transformation, facilitating the rapid growth of the financial system.

Growth differences between the two aggregates, SM1 versus DM1 and SM2 versus DM2, are plotted in Figures 4 and 5 respectively. As observed, the movement in the growth rates of M1 is more volatile than those of M2, regardless 
Figure 3:

Divisia index M2 (DM2) and simple-sum M2 (SM2)

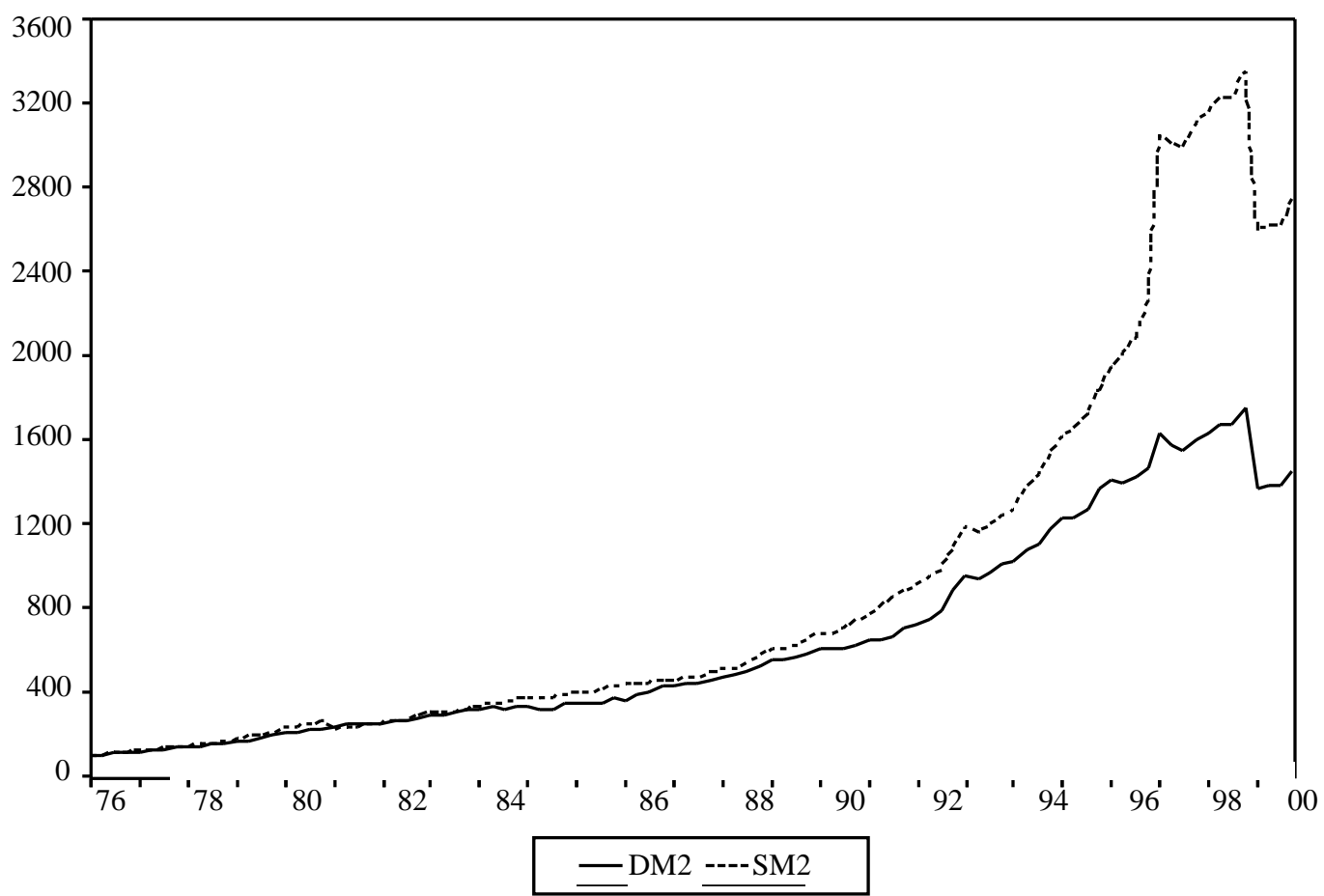

Figure 4:

Annual growth of Divisia Index M1 (GDM1) and simple-sum M1 (GSM1)

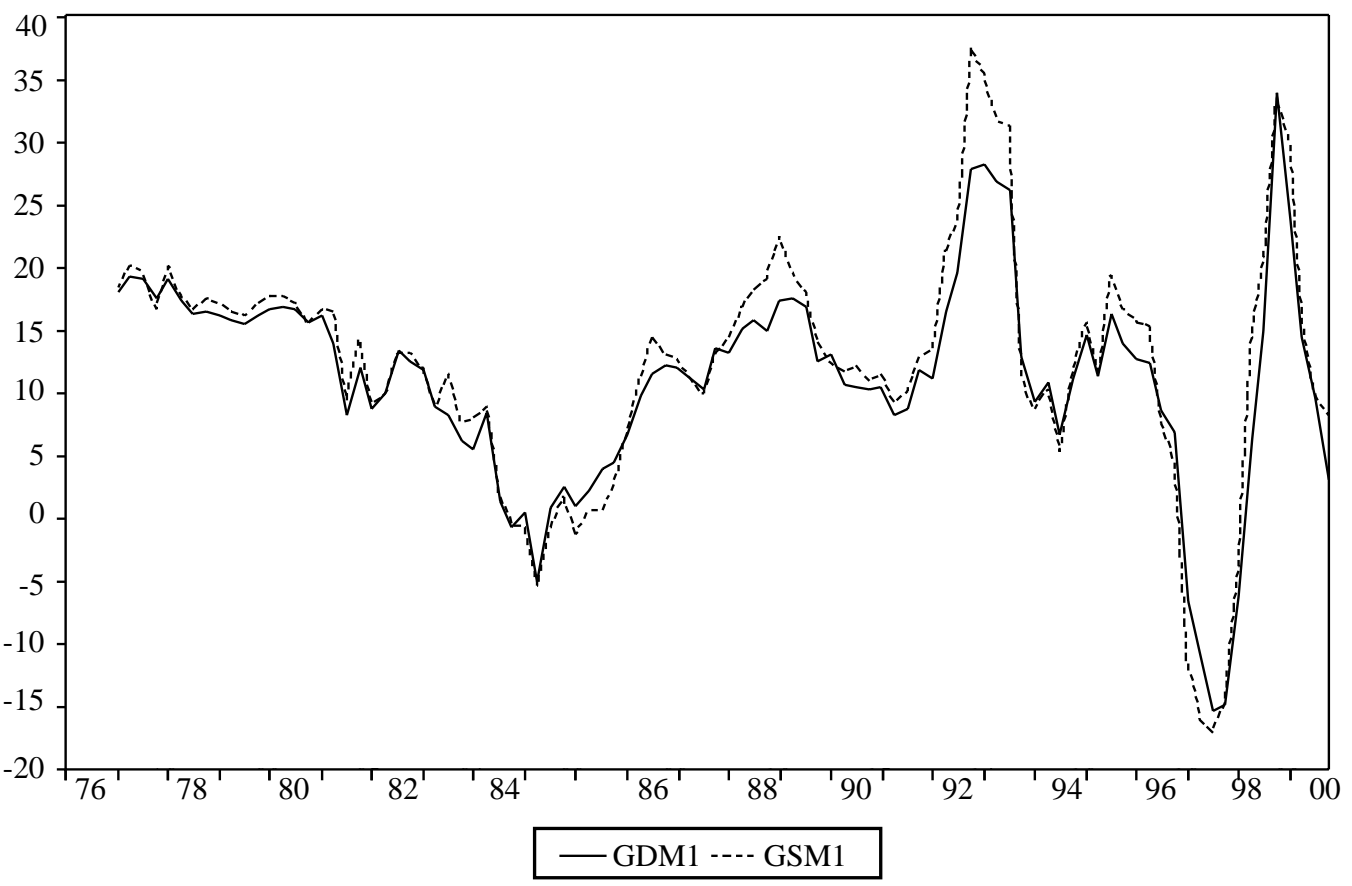


of the aggregation procedure adopted. As to the comparison made between Divisia and simple-sum M1, the difference seems much smaller and the series are highly correlated as shown in Figure 4.

The correlation coefficient of the growth rates of the monetary aggregates in Table 1 also suggests that Divisia M1 and simple-sum M1 are highly correlated as compared to their counterparts for M2 over the sample period. As for developed economies such as Japan, similar results of highly correlated growth rates of the narrowly defined monetary aggregates of simple-sum and Divisia index were also reported (Ishida, \& Nakamura, 2000). The correlation coefficients which is slightly lower than M1 monetary aggre- gate is also reported for simple-sum and Divisia M2+CDs for Japan.

The standard deviations of the growth rates of the monetary aggregates as shown in Table 1 also indicate that movements of the simplesum aggregates M1 and M2 are more volatile as compared to Divisia M1 and M2. Ishida and Nakamura (2000), nevertheless, show of a lower volatility for growth rates of Divisia index than the simple-sum of monetary aggregates M1 and M2 for Japan within a sample period 1970Q1 to 1994Q1. For the US, Thornton and Yue (1992) show that for broader definition of simple-sum monetary aggregates the growth rates are larger compared to the corresponding Divisia measures.

Figure 5:

Annual growth of divisia index M2 (GDM2) and simple-sum M2 (GSM2)

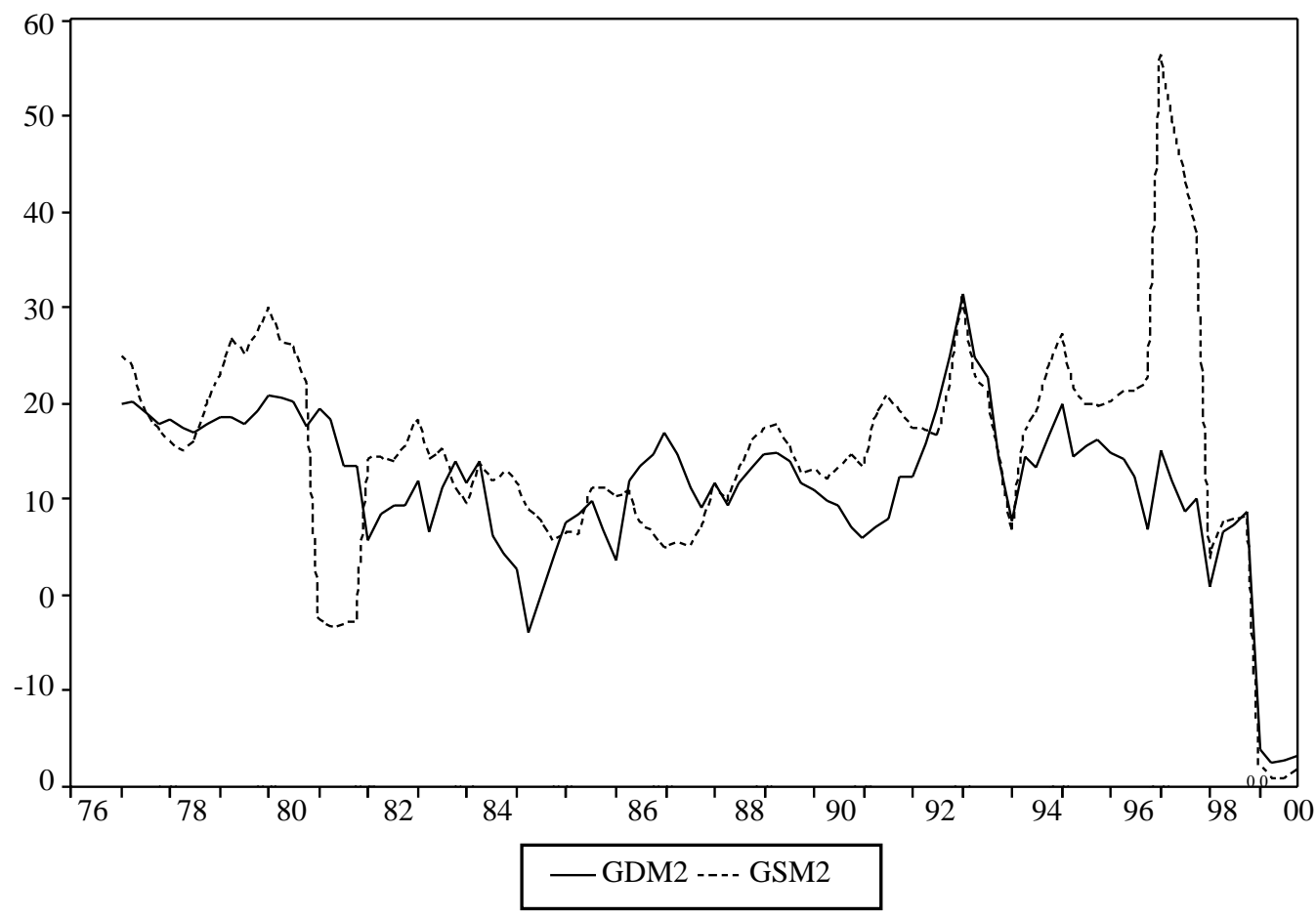

As in the case of the broad monetary aggregate $\mathrm{M} 2$, a significant difference in the movements of the growth rates of DM2 and SM2 can be seen in Figure 5. Generally, Divisia M2 records lower growth rates than simple-sum M2 except for two occasions, 1981 when the country experienced a slowdown in economy as a result of the dampening effects of the worldwide recession, and 1987-88 when the interest rates, especially deposit rates declined rapidly as monetary policy tried to stimulate private investment after the of recession 1986-87. 
Income velocities for DM1 and SM1, and DM2 and SM2 are plotted in Figures 6 and 7, respectively. These income velocities which are based on nominal gross domestic product (GDP), are taken as a proxy for the volume of transactions. The velocity is simply the nominal GDP divided by the relevant monetary aggregate. The velocities of simple-sum M1 and M2 generally exhibit a downward trend, except for a short period in 1997 when M1 velocity increased momentarily but then decrease due to the financial crisis. Similar experience is also observed for velocity of simple-sum M2 in 1999. During the period 1989-1993, velocity for simple-sum M1 decrease due to the sharp increase in the demand for transactions balances relative to the growth in income arising from the accumulated wealth effect created from the bullish stock market.
The simple-sum M1 velocity trend could also be explained in terms of the rapid growth and increasing stability of the banking system and the spread of financial intermediation (Bank Negara Malaysia, 1994). The downward trend in the velocity of simple-sum M2 is mainly attributed to the rapid growth of the commercial banks and their deposit base, in particular fixed and savings deposits and other deposit substitutes including negotiable certificates of deposit and repurchase agreements. The velocities of the Divisia M1 and M2, on the other hand, exhibit relatively stable patterns. Hence, it appears that the Divisia index yield velocity measures that behave quite uniformly across various monetary aggregates. Financial innovations and deregulations generally would tend to make demand for monetary assets more interest elastic and the movements of the Divisia monetary aggregates seem to be in line with this conjecture.

Figure 6:

Income velocities of divisia index M1 (VDM1) and simple-sum M1 (VSM1)

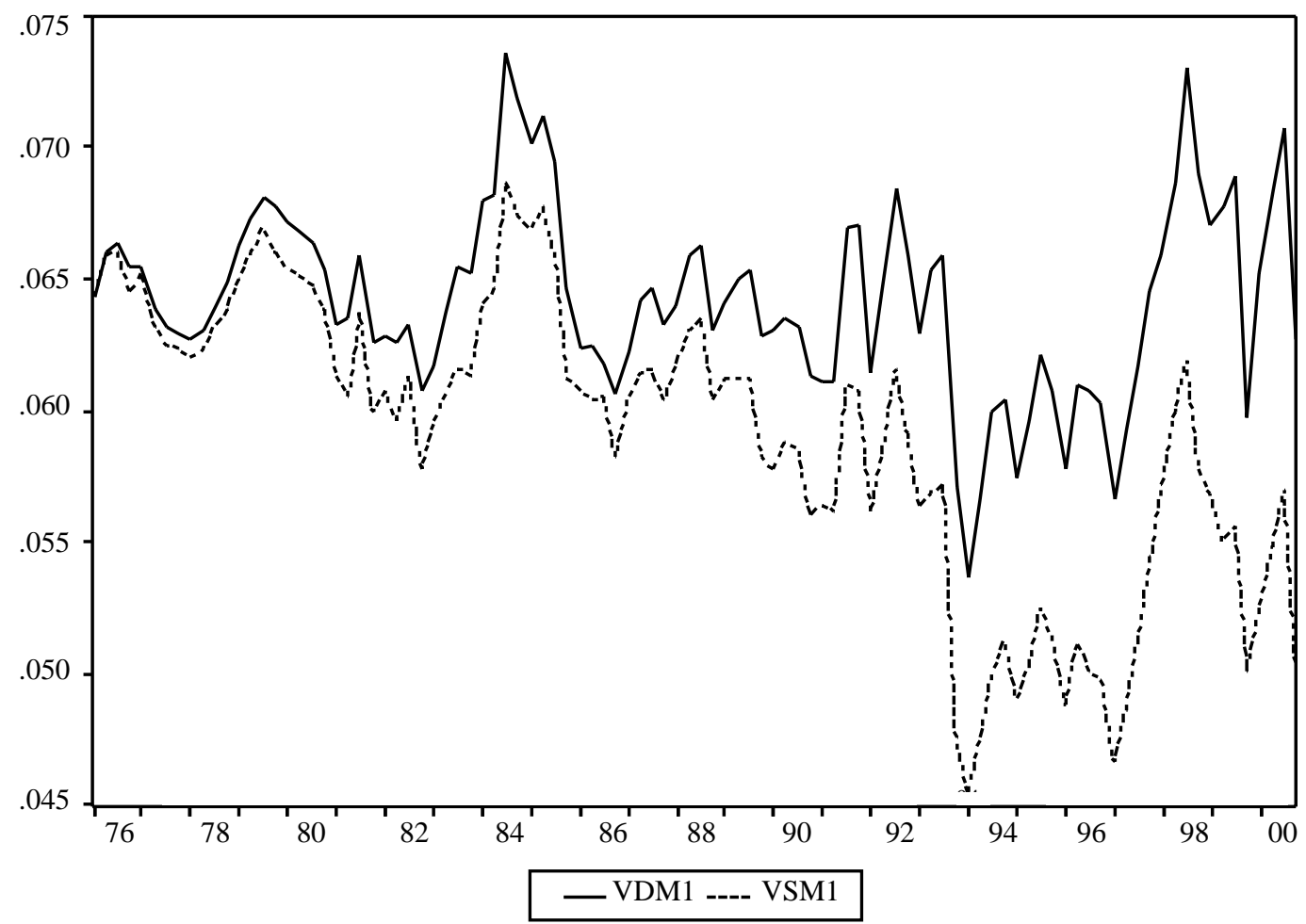


Figure 7:

Income velocities of divisia index M2 (VDM2) and simple-sum M2 (VSM2)

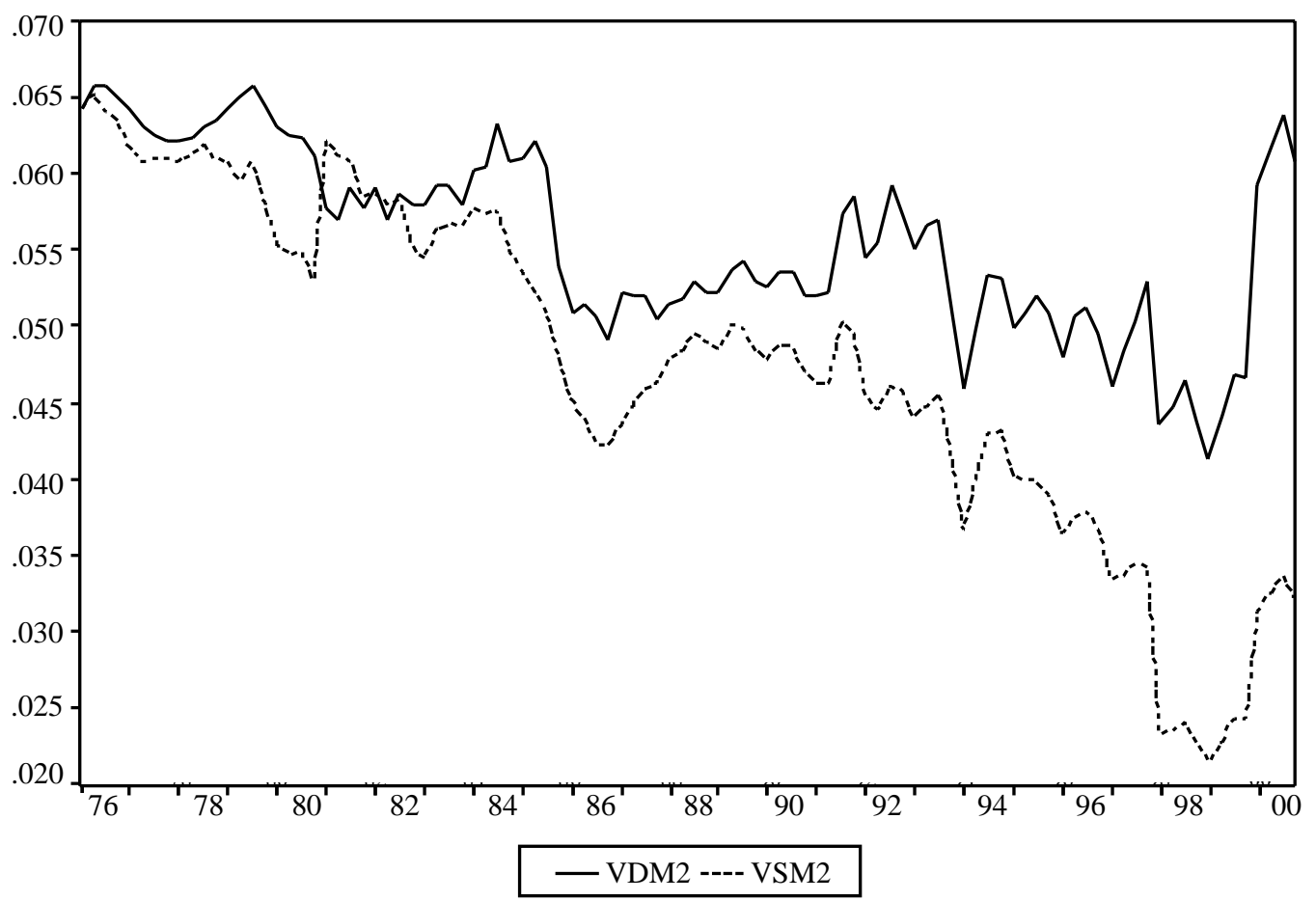

EMPIRICAL RESULTS

The usefulness of the alternative monetary aggregate measures is investigated. It is the interest of this study to look at how the performance of the various alternative monetary aggregates with respect to their usefulness in formulating monetary policy. In order to determine whether a monetary aggregate can be used as a target or indicator in formulating the monetary policy by the Central Bank, the relationship between the monetary aggregates and some key economic variable, such as inflation is examined.

Before conducting cointegration tests, it is important to begin with an investigation of the properties of the time series we are dealing with in order to avoid spurious results. Each individual series should be integrated of order one. The series we examine are Divisia index M1 and M2, simple-sum M1 and M2, and inflation. Table 2 presents the results of the Augmented DickeyFuller (ADF) unit root tests to establish the stationarity of the time series. In general, the results indicate strongly that null hypothesis of a unit root in all series tested cannot be rejected. Subsequently, the tests for unit root are again performed on the first differences of the series, and the results are also provided in Table 2. This tests results convincingly rejected the presence of the unit root in all series at 10 percent significant level. Thus, the first difference of all series are stationary and we can conclude that the series tested are integrated of order one, I (1).

To facilitate a comparison of the performance of the alternative monetary aggregates, an analysis of the long-run relationship between alternative monetary aggregates and inflation is of some interest. Such a relationship exists if the variables are cointegrated. The results of this cointegration test between inflation and alternative measures of monetary aggregate are given in Table 3. Both the Dickey-Fuller (DF) and augmented Dickey-Fuller (ADF) clearly reject the null hypothesis of unit root at 5 percent level of sig- 
nificant, which can be concluded as significant evidence of the existence of cointegration between inflation and the alternative measures of monetary aggregate. Thus, the long-run relationship between the two variables that is the inflations and the alternative measures of monetary aggregates can be expressed as below:

$$
Y_{t}=\beta_{0}+\beta_{1} X_{t}+u_{t}
$$

where $\mathrm{Y}$ represents inflations and $\mathrm{X}$ represents the various measures of monetary aggregates, Divisia M1, Divisia M2, simple-sum M1 and simple-sum M2. All of the variables are in logarithm. Except for inflations, the various measures of monetary aggregates are in real term.
We also estimated the effect of the growth of each monetary aggregate on the inflation rate using an error-correction model. The results of the estimation of error-correction models are given in Table 4 . The appropriate number of lags in the models of each measure of monetary aggregates is determined by Akaike information criteria in which it is determined as four. The Durbin-Watson statistics for each model significantly indicates no evidence of the presence of serial correlation presents in each estimated model which reflect soundness of the models estimated and the computed adjusted $\mathrm{R}$ square for all estimated models are also satisfactory. Additionally, all the error-correction terms in all estimated models are correct which shows that the deviations of the inflation from the long-run equilibrium. These deviations are corrected in the next period.

Table 1:

Summary of Statistics for Divisia and Simple-Sum Monetary Aggregates

\begin{tabular}{|c|c|c|c|c|}
\hline & \multicolumn{2}{|c|}{ Narrow Money } & \multicolumn{2}{|c|}{ Broad Money } \\
\hline & SMI & $\overline{D M 1}$ & SM2 & $D M 2$ \\
\hline Mean & 12.33 & 11.22 & -14.83 & 11.60 \\
\hline Std.Deviation & \multirow{2}{*}{\multicolumn{2}{|c|}{0.97}} & 11.95 & 8.31 \\
\hline Corr. Coefficient & & & \multicolumn{2}{|c|}{0.62} \\
\hline
\end{tabular}

Table 2:

Unit Root Tests - Log Variables

\begin{tabular}{|c|c|c|c|c|c|c|c|}
\hline \multirow[b]{3}{*}{ Log level } & \multirow[b]{3}{*}{ Lags } & \multicolumn{2}{|c|}{ ADF Test } & \multirow[b]{3}{*}{$\begin{array}{l}\text { Log first } \\
\text { difference }\end{array}$} & \multirow[b]{3}{*}{ Lags } & \multicolumn{2}{|c|}{ ADF Test } \\
\hline & & Model 1 & Model 2 & & & Model 1 & Model 2 \\
\hline & & $t_{a^{*}}$ & $t_{a}$ & & & $\overline{t_{\alpha^{*}}}$ & $\overline{t_{\alpha}}$ \\
\hline$D M 1$ & 8 & -0.32 & -2.42 & $\Delta D M 1$ & 7 & $-2.86 * * *$ & -2.76 \\
\hline$D M 2$ & 0 & -1.75 & -1.70 & $\Delta D M 2$ & 0 & $-10.32 *$ & $-10.50^{*}$ \\
\hline$S M 1$ & 8 & -0.04 & -2.34 & $\Delta S M 1$ & 7 & $-2.79 * * *$ & -2.69 \\
\hline$S M 2$ & 0 & -0.59 & -1.76 & $\Delta S M 2$ & 0 & $-9.46^{*}$ & $-9.42 *$ \\
\hline$I N F L$ & 4 & -1.29 & -2.52 & $\triangle I N F L$ & 2 & $-3.96 *$ & $-4.24 *$ \\
\hline \multicolumn{8}{|c|}{ Critical Value } \\
\hline & $1 \%$ & -3.51 & -4.05 & & & -3.51 & -4.05 \\
\hline & $5 \%$ & -2.89 & -3.45 & & & -2.89 & -3.45 \\
\hline & $10 \%$ & -2.58 & -3.15 & & & -2.58 & -3.15 \\
\hline
\end{tabular}

$* / * * / * * *$ Significant at $1 \%, 5 \%$, and $10 \%$ respectively.

SM1: Simple-sum M1, SM2: Simple-sum M2, DM1: Divisia M1, DM2: Divisia M2, INF: inflation. All variables are in real. 
Table 3:

Cointegration Test Between Inflation and Monetary Aggregates

\begin{tabular}{llllll}
\hline Monetary aggregates & DF - Test & ADF - Test & \multicolumn{3}{c}{ Critical value } \\
& & & $1 \%$ & $5 \%$ & $10 \%$ \\
\hline SM1 & $-7.58^{*}$ & $-3.99^{*}$ & -4.014 & -3.402 & -3.089 \\
SM2 & $-7.65^{*}$ & $-4.04^{*}$ & -4.014 & -3.402 & -3.089 \\
DM1 & $-7.63^{*}$ & $-4.03^{*}$ & -4.014 & -3.402 & -3.089 \\
DM2 & $-7.58^{*}$ & $-3.99^{*}$ & -4.014 & -3.402 & -3.089 \\
\hline
\end{tabular}

$* / * * / * * *$ Significant at $1 \%, 5 \%$, and $10 \%$ respectively.

SM1: Simple-sum M1, SM2: Simple-sum M2, DM1: Divisia M1, DM2: Divisia M2,

Critical values from MacKinnon's (1991) response surface functions: $C(\alpha, T)=K_{\infty}+K_{1} / T+K_{2} / T^{2}$

Table 4:

Error Correction Model of Monetary Aggregates SM1 and DM1

\begin{tabular}{|c|c|c|c|c|c|c|c|c|c|c|c|c|}
\hline \multicolumn{13}{|c|}{$\Delta \log I N F L_{t}=$ Const $+E C T_{t-1}+\sum_{i=1}^{4} \Delta \log I N F L_{t-i}+\sum_{i=1}^{4} \Delta \log M_{t-i}+\varepsilon$} \\
\hline \multicolumn{5}{|l|}{ Model } & \multicolumn{5}{|c|}{ Explanatory variables } & \multicolumn{3}{|c|}{$\mathrm{ADJR}^{2 D W}$} \\
\hline \multicolumn{13}{|l|}{ a) SM1 } \\
\hline \multirow[t]{4}{*}{$I N F L_{t}$} & Const & $E C T_{t-1}$ & $I N F L_{t-1}$ & $I N F L_{t-2}$ & $I N F L_{t-3}$ & $I N F L_{t-4}$ & $S M 1_{t-1}$ & $S M 1_{t-2}$ & $S M 1_{t-3}$ & $S M 1_{t-4}$ & & \\
\hline & -0.001 & $-0.321 *$ & $-0.338 *$ & -0.134 & $-0.316^{*}$ & 0.025 & $0.052^{*}$ & -0.011 & $-0.030 *$ & $0.035^{*}$ & & \\
\hline & $(0.0008)$ & $(0.142)$ & $(0.156)$ & $(0.150)$ & $(0.137)$ & $(0.101)$ & $(0.018)$ & $(0.019)$ & $(0.018)$ & $(0.019)$ & & \\
\hline & {$[-1.250]$} & {$[-2.261]$} & {$[-2.167]$} & {$[-0.889]$} & {$[-2.310]$} & {$[0.804]$} & [2.889] & {$[-0.570]$} & {$[-1.667]$} & {$[1.858]$} & 0.51 & 2.06 \\
\hline \multicolumn{13}{|l|}{ b) DM1 } \\
\hline \multirow[t]{4}{*}{$I N F L_{t}$} & Const & $E C T_{t-1}$ & $I N F L_{t-1}$ & $I N F L_{t-2}$ & $I N F L_{t-3}$ & $I N F L_{t-4}$ & $D M 1_{t-1}$ & $D M 1_{t-2}$ & $D M 1_{t-3}$ & $D M 1_{t-4}$ & & \\
\hline & -0.0012 & $-0.305^{*}$ & $-0.382 *\}$ & -0.1400 & $-0.294 *$ & 0.031 & $0.052^{*}$ & 0.0004 & -0.024 & $0.040^{*}$ & & \\
\hline & $(0.0008)$ & $(0.142)$ & $(0.1559)$ & $(0.149)$ & $(0.138)$ & $(0.100)$ & $(0.018)$ & $(0.019)$ & $(0.019)$ & $(0.02)$ & & \\
\hline & {$[-1.367]$} & {$[-2.148]$} & {$[-2.452]$} & {$[-0.9343]$} & {$[-2.130]$} & [0.307] & [2.817] & {$[0.023]$} & {$[-1.277]$} & [2.000] & 0.52 & 2.03 \\
\hline
\end{tabular}

$* / * *$ Significant at $5 \%$ and $10 \%$ respectively. Lags determination based on AIC (Akaike information criteria). Standard error in parentheses, t-statstics in bracket. $A D J R_{-}$is adjusted $\mathrm{R}$ and $D W$ is Durbin-Watson statistics. $I N F L$ is the inflation. $S M 1$ is the simple-sum M1, DM1 is the Divisia M1 and ECT is the error correction term.

Using the estimated error-correction models of the alternative monetary aggregate measures we then performed out-of sample forecast of inflations for three periods. The error-correction terms are included in all models when forecasting inflation because they were all significant. The first period of forecasts, the error-correction models of the alternative monetary aggregates measures are estimated for the period of 1987Q1 to 1994Q4 and out-of sample forecast is made for the period of 1995Q1 to 1997Q4. The models of estimation are then updated to 1995Q4 and the second period of out-of sample forecasting that is, 1996Q1 to $1997 \mathrm{Q} 4$, are then performed. Finally, the models are estimated from 1976Q1 to
1996Q4 and the third period of out-sample forecast is then conducted for 1997Q1 to 1997Q4. The statistics of the results from the forecast of inflations over three different periods by the error-correction models of all the alternative measures of the monetary aggregates are given in Table 5 .

The results indicate that the root mean squared error (RMSE) and mean absolute error (MABE) of the Divisia monetary aggregates M1 and $\mathrm{M} 2$ are smaller than their simple-sum counterparts which indicate a better forecasting ability by the model of the Divisia monetary aggregate. With reference to the mean absolute percentage error (MABPE), the model for the Divisia monetary aggregate produce smaller percentage 
as opposed to their simple-sum counterparts in all three forecasting period, with one exception noted whereby the MABPE for model of Divisia monetary aggregate M2 recorded slightly higher percentage than its counterpart simple-sum M2 for the period of forecast 1995Q1 to 1997Q4. Nevertheless, the error-correction model for Divisia monetary aggregate performs better than their sim- ple-sum counterpart of monetary aggregate in forecasting ability of inflations. The overall results of this empirical investigations thus reflect a high degree of usefulness of the alternative measures of the Divisia monetary aggregate especially the broad money of Divisia M2 as a candidate for target or indicator that can be used as a benchmark by the central bank of Malaysia in formulating the monetary policy.

Table 5:

Error Correction Model of Monetary Aggregates SM2 and DM2

\begin{tabular}{|c|c|c|c|c|c|c|c|c|c|c|c|c|}
\hline \multicolumn{13}{|c|}{$\Delta \log I N F L_{t}=$ Const $+E C T_{t-1}+\sum_{i=1}^{4} \Delta \log I N F L_{t-i}+\sum_{i=1}^{4} \Delta \log M_{t-i}+\varepsilon_{t}$} \\
\hline \multicolumn{5}{|l|}{ Model } & \multicolumn{5}{|c|}{ Explanatory variables } & \multicolumn{3}{|c|}{$\mathrm{ADJR}^{2 \mathrm{DW}}$} \\
\hline \multicolumn{13}{|l|}{ a) $\mathrm{SM} 2$} \\
\hline \multirow[t]{4}{*}{$I N F L_{t}$} & Const & $E C T_{t-1}$ & $I N F L_{t-1}$ & $I N F L_{t-2}$ & $I N F L_{t-3}$ & $I N F L_{t-4}$ & $S M 1_{t-1}$ & $S M 1_{t-2}$ & $S M 1_{t-3}$ & $S M 1_{t-4}$ & & \\
\hline & -0.001 & $-0.375^{*}$ & $-0.416^{*}$ & -0.225 & $-0.293^{*}$ & 0.010 & $0.025 * *$ & -0.011 & 0.008 & 0.026 & & \\
\hline & $(0.0009)$ & $(0.146)$ & $(0.157)$ & $(0.145)$ & $(0.132)$ & $(0.104)$ & $(0.013)$ & $(0.014)$ & $(0.014)$ & $(0.017)$ & & \\
\hline & {$[-1.286]$} & {$[-2.569]$} & {$[-2.65]$} & {$[-1.552]$} & {$[-2.221]$} & [0.099] & [1.923] & {$[-0.782]$} & {$[0.566]$} & [1.529] & 0.48 & 1.94 \\
\hline \multicolumn{13}{|l|}{ b) $\mathrm{DM} 2$} \\
\hline \multirow[t]{4}{*}{$I N F L_{t}$} & Const & $E C T_{t-1}$ & $I N F L_{t-1}$ & $I N F L_{t-2}$ & $I N F L_{t-3}$ & $I N F L_{t-4}$ & $D M 1_{t-1}$ & $D M 1_{t-2}$ & $D M 1_{t-3}$ & $D M 1_{t-4}$ & & \\
\hline & $-0.002 * *$ & $-0.363^{*}$ & $-0.420^{*}$ & -0.204 & $-0.326^{*}$ & -0.014 & $0.047 *$ & -0.006 & -0.0003 & $0.056^{*}$ & & \\
\hline & $(0.001)$ & $(0.141)$ & $(0.152)$ & $(0.141)$ & $(0.129)$ & $(0.101)$ & $(0.017)$ & $(0.017)$ & $(0.017)$ & $(0.026)$ & & \\
\hline & {$[-1.881]$} & {$[2.561]$} & {$[2.751]$} & {$[-1.451]$} & {$[2.521]$} & {$[-0.143]$} & [2.731] & {$[-0.353]$} & {$[-0.019]$} & [2.154] & 0.52 & 2.07 \\
\hline
\end{tabular}

*/** Significant at $5 \%$ and $10 \%$ respectively. Lags determination based on AIC (Akaike information criteria). Standard error in parentheses, t-statstics in bracket. $A D J R^{2}$ is adjusted $\mathrm{R}^{2}$ and $D W$ is Durbin-Watson statistics. $I N F L$ is the inflation. SM2 is the simple-sum M2, DM2 is the Divisia M2 and ECT is the error correction term.

Table 6:

Forecast of Inflation Based on Error Correction Model

\begin{tabular}{|c|c|c|c|c|c|c|c|c|c|c|c|c|}
\hline \multirow[b]{2}{*}{ Forecast statistics } & \multirow[b]{2}{*}{ SM1 } & \multicolumn{3}{|c|}{$\begin{array}{l}\text { Forecast period: } \\
\text { 1995Q1-1997Q4 }\end{array}$} & \multirow[b]{2}{*}{ SM1 } & \multicolumn{3}{|c|}{$\begin{array}{c}\text { Forecast period: } \\
\text { 1996Q1-1997Q4 }\end{array}$} & \multirow[b]{2}{*}{ SM1 } & \multicolumn{3}{|c|}{$\begin{array}{c}\text { Forecast period: } \\
\text { 1997Q1-1997Q4 }\end{array}$} \\
\hline & & DM1 & SM2 & DM2 & & DM1 & SM2 & DM2 & & DM1 & SM2 & DM2 \\
\hline$R M S E\left(\_10^{-2}\right)$ & 0.378 & 0.209 & 0.305 & 0.236 & 0.379 & 0.325 & 0.350 & 0.209 & 0.437 & 0.335 & 0.399 & 0.337 \\
\hline $\operatorname{MABE}\left({ }_{-} 10^{-2}\right)$ & 0.307 & 0.228 & 0.248 & 0.201 & 0.299 & 0.243 & 0.305 & 0.217 & 0.353 & 0.249 & 0.371 & 0.219 \\
\hline MABPE & 471.40 & 364.17 & 306.43 & 313.38 & 606.96 & 484.54 & 415.34 & 403.12 & 59.17 & 45.09 & 67.37 & 46.98 \\
\hline
\end{tabular}

$R M S E$ is Root means squared error, $M A B E$ is mean absolute error, $M A B P E$ is mean absolute percentage error. All figures form RMSE and MABE are multiply by $10^{-2}$. 


\section{CONCLUDING REMARKS}

The theoretical advantage of the Divisia index has now taken the forefront in many monetary analyses. Many central banks of the developed economies have developed database on Divisia indices for monetary aggregates. Nevertheless, the Central Bank of Malaysia (BNM) does not use a Divisia index. Formulating of monetary policy by the central bank of Malaysia is still reliant on the traditional simple-sum method of monetary aggregation. In this study we investigated empirically the various measures of monetary aggregates namely, the Divisia M1, simple-sum M1, Divisia M2 and simple-sum M2. Unlike the narrowly defined monetary aggregate, the method of aggregation for broader defined monetary aggregate M2 does show significant differences in both level and growth rates, thereby suggesting the importance of measuring monetary aggregates appropriately.

We ascertained that there exists long-run relationship between all measures of monetary aggregates in this study with inflation. By constructing the dynamic error-correction models for the alternative measures of monetary aggregates, we performed out-of sample forecasting for three different periods and compared the forecasting ability of Divisia monetary aggregates namely Divisia M1 and M2, with their simple-sum counterparts that is, M1 and M2. Analysis of the forecasting statistics indicates that the Divisia monetary aggregates performed better than their simple-sum counterparts in forecasting ability. However, Habibullah (1998) used the P-Star model approach in determining inflation in Malaysia. Contrary to our results, he concludes that the Divisia index (Malaysia's monetary data) does not support the P-Star approach in modeling inflation. In reference to the objective of the Central Bank of Malaysia to maintain price stability, we thus conclude that the Divisia monetary aggregates, particularly the Divisia M2, is a viable candidate for target or indicator in formulating the monetary policy in Malaysia.

\section{REFERENCES}

Anderson, R. G., Jones, B. E, \& Nesmith, T. D. (Jan-Feb,1997). Building new monetary services indexes: concept, data, and methods. Federal Reserve Bank of St. Louis Review. 53-82.

Bank Negara Malaysia. (1994). Money and banking in Malaysia. Kuala Lumpur: Bank Negara Malaysia.

(1999). The central bank and the financial system in Malaysia. Kuala Lumpur: Bank Negara Malaysia.

Barnett, W. A. (1978). The user cost of money. Economics Letters, 1, 145-149.

(1980). Economic monetary aggregates: an application of index number and aggregation theory. Journal of Econometrics, 14, 11-48.

(1982). The optimal level of monetary aggregation. Journal of Money, Credit and Banking, 14 (4), 687710.

Barnett, W. A., Fisher, D., \& Serletis, A. (1992). Consumer theory and the demand for money. Journal of Economic Literature, 30, 2086-2119.

Barnett, W. A., Offenbacher, E., \& Spindt, P (1981). New concepts of aggregated money. Journal of Finance, 36, 497-505.

Barnett, W. A., Offenbacher, E., \& Spindt, P. (1984). The new Divisia monetary aggregates. Journal of Political Economy, 92, 1049-1085.

Barnett, W. A., \& Spindt, P. A. (May, 1982). Divisia monetary aggregates: compilation, data, and historic behavior. Board of Governors of the Federal Reserve System. Staff Study 116. 
Belongia, M. T., \& Chrystal, K. A. (1991). An admissible monetary aggregate for the United Kingdom. The Review of Economics and Statistics, 73 (3), 497-503.

Chou, N. T. (1991). An alternative monetary policy target: the new benchmark Divisia monetary index. Applied Economics, 23, 1699-1705.

Cockerline, J. P., \& Murray, J. D. (1981). A comparison of alternative methods of monetary aggregation: some preliminary evidence. Bank of Canada Technical Reports, 28.

Engle, F. R., \& Granger, C. W. J. (1987). Co-integration and error correlation: representation, estimation, and testing. Econometrica, 55, 251-276.

Fluri, R., \& Spoerndli, E. (2000). Simple-sum versus money in Switzerland: Some empirical results. In M. T. Belongia., \& J. M. Binner., (Eds), Divisia monetary aggregate: theory and practice. New York: Palgrave.

Friedman, M., \& Schwartz, A. J. (1970). Monetary statistics of the United States: estimates, sources, methods, and data. New York: Columbia University Press.

Habibullah, M. S. (Jun-Dec. 1998). The application of the P-Star approach of modelling inflation in a developing country: The case of Malaysia. Analisis, 5 (1-2), 3345.

(1999). Divisia Monetary aggregates and economic activities in Asian developing economies, Aldershot, England: Ashgate Publishing Ltd.

Ishida, K. (June, 1984). Divisia monetary aggregates and demand for money: a Japanese case. Bank of Japan Monetary and Economic Studies, 2 (1), 44-86.
Ishida, K., \& Nakamura, K. (2000). Broad and narrow Divisia monetary aggregates for Japan. In M. T. Belongi, \& J. M. Binner, (Eds.), Divisia monetary aggregate: theory and practice. New York: Palgrave.

Janssen, N. G. J., \& Kool, C. J. M. (2000). Weighted Dutch and Germany monetary aggregates: how do they perform as monetary indicators for the Netherlands? In M. T. Belongia, \& J. M. Binner, (Eds). Divisia monetary aggregate: theory and practice. New York: Palgrave.

Klein, B. (1974). Competitive interest payments on bank deposits and the long-run demand for money. The American Economic Review, 64 (6), 931-949.

Lim, G. C., \& Martin, V. L. (2000). Weighted monetary aggregates: empirical evidence for Australia. In M. T. Belongia, $\&$ J. M. Binner, (Eds). Divisia monetary aggregate: theory and practice. New York: Palgrave.

Serletis, A., \& King, M. (1993). Role of money in Canada. Journal of Macroeconomics, 15 (1), 91-107.

Spencer, P. (1994). Portfolio disequilibrium: implications for the divisia approach to monetary aggregation. The Manchester School, 62 (2), 125-150.

Starz, R. (Oct, 1979). Implicit interest on demand deposits. Journal of Monetary Economics, 515-534.

Thornton, D. L., \& Yue, P. (Nov-Dec,1992). An extended series of Divisia monetary aggregates. Federal Reserve Bank of St. Louis Review, 35-52.

Yue, P., \& Fluri, R. (Sept-Oct, 1991). Divisia monetary services indexes for Switzerland: are they useful for monetary targeting. Federal Reserve Bank of St. Louis Review, 19-33 